\title{
THE SUPREME COURT OF CANADA: EXTENDING THE TORT LIABILITY OF PUBLIC AUTHORITIES
}

\author{
LEWIS N. KLAR*
}

Professor Klar discusses the recent Supreme Cour of Canada trilogy dealing with the common law liability of public authorities for nuisance and negligence. Just $v$. R. in Right of B.C. deals with the distinction between policy decisions made by the government, which are not reviewable by the courts, and the operational activities of public authorities which are subject to the ordinary principles of tort law. Rothfield $v$. Manolakos, a case dealing with the negligence of building inspectors, follows the principle set out in Just. Professor Klar concludes that this, 10o, creates an increase in the potential tort liability of public authorities. The final case in the trilogy, Tock v. St. John's Metropolitan Area Board, yields three differing judgments dealing with the defence of statutory authority with respect to a claim for nuisance. Professor Klar concludes that the three judgments in Tock are similar, at least to the extent that each would limit the application of the defence of statutory authority in nuisance claims. After providing some insights into the results of each of these cases individually, the author concludes that the overall result of the trilogy is an expansion of the vulnerability of pubic authorities to tort action.
Le Professeur Klar étudie les trois décisions récentes de la Cour suprême du Canada traitant de la responsabilité civile des pouvoirs publics en matière de nuisance et de négligence. Just $c$. $R$. dans Right of B.C. porte sur la distinction existant entre les décisions administratives du gouvemement qui ne peuvent être réexaminées par les tribunaux, et les activités opérationnelles des pouvoirs publics, lesquelles activités sont assujetties aux principes ordinaires de la responsabilité civile. Rothfield $c$. Manolakos, qui a pour sujet la négligence des inspecteurs de la construction, suit le principe énoncé dans Just; selon le Professeur Klar, voilà qui contribue à augmenter la responsabilité civile des pouvoirs publics. Le troisième cas a l'étude, Tock $c$. St. John's Metropolitan Area Board, donne lieu à trois jugements divergents quant a la défense de l'administration légalement compétente devant une créance en nuisance. L'auteur note que les trois décisions dans Tock sont similaires, tout du moins en ce que chacune limite l'application des moyens de défense de l'administration légalement compétente en matière de réclamation fondée sur une nuisance. Après des commentaires pénétrants sur les résulhats de chacun des cas, l'auteur conclut que, pris globablement, ils étendent la vulnérabilité des pouvoirs publics à l'action délictuelle.

\section{TABLE OF CONTENTS}

I. INTRODUCTION

II. JUST v. R. IN RIGHT OF B.C.:

THE "POLICY/OPERATIONAL" DICHOTOMY .....

A. INTRODUCTION $\ldots \ldots \ldots \ldots \ldots \ldots \ldots \ldots \ldots \ldots, 650$

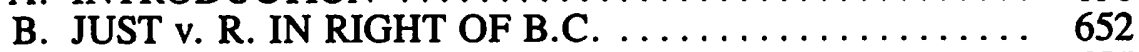

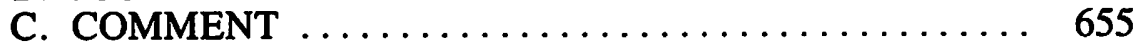

III. ROTHFIELD v. MANOLAKOS: LIABILITY OF

NEGLIGENT BUILDING INSPECTORS $\ldots \ldots \ldots \ldots \ldots$

A. THE CASE $\ldots \ldots \ldots \ldots \ldots \ldots \ldots \ldots \ldots \ldots \ldots$

B. COMMENT

IV. TOCK v. ST. JOHN'S METROPOLITAN

AREA BOARD: THE DEFENCE OF STATUTORY

AUTHORITY IN THE LAW OF NUISANCE . . . . . .

A. INTRODUCTION $\ldots \ldots \ldots \ldots \ldots \ldots \ldots \ldots \ldots \ldots, 658$

B. TOCK v. ST. JOHN'S METRO AREA BOARD ...... 659

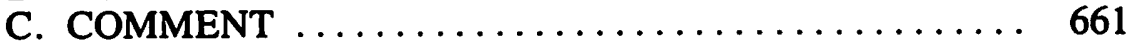

V. CONCLUSION $\ldots \ldots \ldots \ldots \ldots \ldots \ldots \ldots \ldots \ldots \ldots 64$ 


\section{INTRODUCTION}

For the Supreme Court of Canada and the law of torts, exciting developments seem to come in three's. As with its 1978 trilogy on the law of damages, 'the Supreme Court of Canada's recent trilogy on the common law liability of public authorities for negligence and nuisance ${ }^{2}$ is destined to have a profound influence on Canadian tort law. ${ }^{3}$

The current judgments are remarkable in several respects. Those of us who have been critical of the Supreme Court of Canada in the past for its rigidly doctrinal approach to decision making in tort law, with its tendency "to confront in a narrow way the issue placed before it, to limit it as much as possible by the facts of the case, and to decide the question in dispute by avoiding wider and often more legally and socially significant issues that run through the case" ${ }^{4}$ must now clearly proclaim that none of these criticisms are valid with respect to these judgments. ${ }^{5}$ The reasons for judgment rendered in these cases are concerned not only with the interpretation of existing case law, but with the wider social questions which they raise.

The lack of consensus and the wide diversity of views displayed by the Justices is also noteworthy. As we shall see, in two of the cases three separate, and differing, sets of reasons were delivered. How future counsel and judges will determine what was actually decided in these cases poses a very real problem.

Unlike the damages trilogy, where the issues in all of the cases were the same, the current cases deal with different aspects of the liability of public authorities. There is, however, a common denominator to them all. They each, in a significant way, extend the tort liability of public authorities. The result is an increased vulnerability for public authorities to future law suits.

The Supreme Court has "Canadianized" the common law relating to the liability of public authorities. It will take quite a while for the dust to settle. This commentary will attempt to lay out the issues, and provide some first impressions.

1. Andrews v. Grand \& Toy, [1978] 2 S.C.R. 229; Thomton v. Prince George Bd. of School Trustees, [1978] 2 S.C.R. 267; and Teno v. Arnold, [1978] 2 S.C.R. 287.

2. Just v. The Queen In Right of B.C., [1990], I W.W.R. 385, (1989), 64 D.L.R. (4th) 689; Rothfield v. Manolakos, [1990] I W.W.R. 408, (1989), 63 D.L.R. (4th) 449; and Tock v. St. John's Metro Area Board (1989), 64 D.L.R. (4th) 620).

3. There is as well a fourth imponant judgment from Quebec, decided several months earlier by the Supreme Court: Laurentide Motels Lid. v. Ciry of Beauport, [1989] 1 S.C.R. 705.

4. L. Klar, "Developments in Tort Law: The 1982-83 Term" (1984) 6 Sup. Ct. L. Rev. 309 at 310.

5. Note, however, that there are eight separate judgments in the three common law cases. I therefore generalize a bit here. 
statutory "discretion", "powers", "policy", or "planning". On the other side are the governmental activities that are subject to tort law's scrutiny; those that involve statutory "duties", "administration", and "operations". '

Despite the terminology, however, it was becoming evident that there is no clear-cut dividing line between the pure policy decisions of government, and the activities undertaken to implement those policies. Admittedly, one can in a rough way distinguish between the decision to do something, and the actual doing of it. The policy phase involves the making of choices, the weighing up of needs and priorities, the deciding of how to best use economic and human resources. Operations involve the implementation of the decision that was taken, by following the standards and directives provided. It is clear, however, that within each sphere there are elements of both. Take, for example, the enacting of legislation, an activity which is clearly "political"'. Even here there are non-discretionary elements - quorum or notice requirements for example. Carelessness in observing these requirements can lead to foreseeable losses. ${ }^{8}$ Should the fact that the activity was "political" immunize the negligent actors? In a similar vein, the implementation of a plan frequently involves the need to constantly make new policy decisions, as the Just case will indicate. Thus, while the policy and operations dichotomy can be seen as a useful starting point in the analysis, it is evident that flexibility is required, the issue not being black and white, but a matter of degrees.

Two important judgments lead up to our present case. In Anns v. Merton London Borough Council' Lord Wilberforce recognized the intertwining of the policy and operational aspects of governmental activities. Nevertheless, based on the factors noted above, one can identify an activity under scrutiny as one primarily concerned with either the exercise of discretion or the implementation of a plan. In this respect, Lord Wilberforce established different "standards" for evaluating the activity for the purposes of a private law action. Questions of policy which involve the exercise of discretion must be approached by public authorities in good faith; the decisions taken must be "within the limits of a discretion bona fide exercised".${ }^{10}$ While not defined, this standard of good faith suggested a test of propriety or legitimacy. In other words, the political actor must take up the task of deciding conscientiously, averting to legitimate factors, and not being swayed by illegitimate ones. With respect to implementation of the decisions, or operations - acts involving little discretion - the standard would be the ordinary private law one; the duty being one of reasonable care.

This approach was taken up in the leading Canadian case of City of Kamloops $\mathrm{v}$. Nielsen. "The majority judgment of Wilson J. recognized the utility of the "policy/operations" dichotomy, as well as its inherent ambiguity. "How do you measure the 'operational' against the 'policy' content of the

7. The "misfeasance/nonfeasance" dichotomy has even incorrectly worked its way into here.

8. As in the case of Welbridge Holdings Ld. v. Metropolitan Corporation of Greater Winnipeg, [1971] S.C.R. 957.

9. [1978] A.C. 728, [1977] 2 All E.R. 492 (H.L.).

10. [1977] 2 All E.R. 492 at 501.

11. [1984] 5 W.W.R. 1, 29 C.C.L.T. 97 (S.C.C.). 
According to the majority, the allegations of negligence which were raised in this case with respect to the manner and quality of the defendant's inspection system fell clearly within the "operational" aspects of the governmental activity. That much is clear. Unfortunately, the reasoning which led to this conclusion is not.

Cory J. conceded that governments ought not to be restricted in making decisions based upon "social, political or economic factors", by subjecting these "true policy decisions" to tortious claims. As an illustration, Cory J. gave the example of a policy decision related to the inspection of lighthouses. A policy decision that funds could not be made available for lighthouse inspection because they were needed elsewhere, would not be subject to a tort law claim, as long this was a bona fide exercise of discretion..$^{19}$ Even a policy decision to reduce the frequency of inspections to once every two years, based on budgetary concerns, would be treated in this way.

So far this is understandable; it is certainly consistent with the traditional approach. However, having said this, Cory J. went on to describe the types of decisions which can be reviewed. Reverting again to the lighthouse example, he stated that once a policy decision to inspect lighthouses is made, "the Court may review the scheme of inspection to ensure it is reasonable and has been reasonably carried out in light of all the circumstances, including the availability of funds, to determine whether the government agency has met the requisite standard of care'". ${ }^{20}$ This is where, with respect, the reasoning breaks down. It is difficult to reconcile (a) the statement that the decision to inspect lighthouses only once every two years based on budgetary concerns is an exempt policy decision, with (b) the statement that once the decision to inspect is made, the scheme of the inspection can be reviewed to ensure it is reasonable.

Despite the confusion with this illustration, the thrust of the majority's decision ultimately became clear. What results is a significant shrinking of the scope of "true policy decisions", with a corresponding expansion of the area called "operations". Extrapolating from the majority's judgment, the following principles emerge. A policy decision is a decision which is made by considering matters of budgetary allocation or other social or political factors. However, not all decisions which involve budgetary allocations or the use of resources can be characterized as a policy decision for the purpose of immunity from tort law review. The "true" policy decisions, which are immune from ordinary tort law principles, are the broad, formulative decisions, generally made by those in high levels of authority. They are what I may describe as "threshold" decisions; they decide in general terms whether something will or will not be done. Details, however, regarding the manner and characteristics of the project fall into the operational aspect of government. This is so notwithstanding the fact that these "details" require decision-making as to the allocation of resources and other such matters. Thus, on the facts of this case, Cory J. held that once the policy decision to have a slope inspection system was made, decisions relating to the manner in which slope inspections were carried out, their frequency

19. Although left unstated, bona fides in this context presumably relates to the concerns of legitimacy raised in both Anns and Kamloops.

20. (1989), 64 D.L.R. (4th) 689 at 707. 
with the times, this is not a time to move". According to Sopinka J. the majority's reasons "would considerably expand the liability for negligence of public authorities by subjecting to judicial review their policy decisions which were hitherto not reviewable". ${ }^{25}$

The dissenting judgment rejected the approach of the majority which would effectively limit the "policy" aspect of governmental activity to the threshold decisions, leaving the entire content of the plan to judicial review. Policy, according to Sopinka J., does not only involve the question of whether to do something, but, as well, the time, manner and technique of doing it. If it were otherwise, very little would be left to policy and most everything would be subject to review.

\section{COMMENT}

The majority's decision in Just has significantly extended the potential tort liability of public authorities. It has certainly exposed hitherto immune public activities to tort law review. To limit the "policy" aspects of governmental activity to the threshold decisions alone, is to virtually remove the immunity, at least as a practical matter. As suggested by Sopinka J., parties are unlikely to attack broad policy decisions by the use of tort law, even if they could. It is the way that these programs are administered which gives rise to "consumer complaints" and tort litigation when injuries arise.

What will happen as a result of the Just case is, of course, uncertain. Certain things can be predicted. There likely will be an increase in public tort litigation. The cases will be more difficult to litigate, and certainly more difficult to try, since it is now necessary to review policy decisions made at the operational level, to determine whether or not they were "reasonable". Courts which have attempted to avoid having to second guess policy makers will have to begin to do precisely that. It may very well be that in view of the inherent difficulties in this task, reviews will be perfunctory in the sense that the courts will accept a very low standard of reasonable care when reviewing policy matters. As a practical matter, it may be very difficult to persuade courts that policy issues decided at the operational level were decided unreasonably by public authorities, in the absence of proof of bad faith. If this turns out to be so, then the results of public tort liability cases, decided after Just, may not differ significantly from the pre-Just decisions. Nevertheless, the litigation undoubtedly will be more costly and time-consuming.

Legislatures may be more inclined to draft specific exemption provisions in their statutes to account for the effect of Just.$^{26} \mathrm{Or}$, threshold decisions which implement programs may now be drafted with greater attention to detail, leaving less discretion to those "in the field" who are asked to implement these programs. This will unfortunately lead to greater inefficiencies and costs, and certainly less flexibility in the hands of those who administer these programs. 
tor's discretionary decision not to require plans by professional engineers, but to rely on on-site inspections to ensure compliance with the by-laws' standards, as being reasonable. However, it was not reasonable to issue a building permit if based on an examination of the specifications and sketches, there were obvious departures from the standards required by the by-laws. La Forest J. determined that negligence in this respect existed in the case, and that the City should be held liable for the losses which occurred, subject to consideration of the effect of the homeowners' own subsequent negligence. La Forest J. further held that the building inspector was negligent in having failed to take steps to remedy the situation once the crack in the wall was discovered by him. It was incumbent on him to order that the work be stopped, and to take whatever corrective measures were necessary to enable him to ensure that the structure was up to standard.

Madame Justice Wilson ${ }^{32}$ held that the City's negligence lay in its failure to follow up its decision to issue the building permit with a notice to the owners that its plan was deficient and that inspections were therefore critical. By issuing the permit in the circumstances of an inadequate design plan, "the City assumed the risk that it could check on the design deficiencies as construction progressed".

Cory $\mathrm{J} .{ }^{33}$ reaffirmed the support he had given to the Anns approach in the $J u s t$ case. It is a "sound" approach which "can be applied effectively and should be applied in any case where negligence or misconduct has been alleged against a government agency" ${ }^{34}$ On the facts of this case, a close relationship of proximity existed between the homeowners and the City's chief building inspector, who issued the building permit, to establish a prima facie duty of care. However, there were considerations to "negative or limit" the scope of the duty, in view of the inspector's public functions. Foremost among these were the obligations which the by-law had placed upon the owners to notify the City that the construction had reached the stage where an inspection was required. If the owners had done so, the City would then have been obliged to "reasonably and properly inspect". Any possible negligence on the City's part in having issued the permit initially was superceded by the owners' later negligence in failing to properly advise the City. However, the same could not be said in relation to the damage suffered by the neighbours of the owners as a result of the collapsed wall. Vis-à-vis them, the City's decision to issue the permit based on inadequate information was negligent and actionable.

The Supreme Court divided three ways with regard to the effect that the owners' negligence ought to have with regard to their claim against the City. La Forest J. held that the owners, although negligent, were not totally to blame for the damages, and an apportionment was ordered. Cory J. held that the owners' negligence absolved the City of its responsibility to them. Wilson J. held that the owners were entitled to rely upon their contractors and the City, and that the owners should bear no responsibility at all for what had occurred.

32. Concurred in by the L'Heureux-Dubé $\mathbf{J}$.

33. Concurred in by Lamer $\mathbf{J}$.

34. (1989), 63 D.L.R. (4th) 449 at 468 , per Cory J. 
these objectives, have been called into play. The second factor in nuisance law's growth has been the absence in the common law of an alternative strict liability principle capable of dealing with the allocation of accident costs arising from socially beneficial, albeit inevitably harmful, activities. In response to the common law's unduly restrictive interpretation of the rule in Rylands v. Fletcher, the less confined principles of nuisance law have been put to use.

Tock v. St. John's Metro Area Board illustrates the category of nuisance cases which deals with problems of accident compensation and cost distribution. At issue was who should pay the accident costs of an activity conducted for the general public's benefit. The Supreme Court of Canada was able to use nuisance law to ensure that these accident costs would be widely distributed.

\section{B. TOCK v. ST. JOHN'S METRO AREA BOARD}

The basement of the appellants' house was flooded by water which came from the respondent Board's obstructed storm sewer system after an exceptionally heavy rainfall. The appellants brought action against the Board alleging the latter's negligence in the construction or maintenance of the sewer, invoking the rule in Rylands v. Fletcher ${ }^{35}$ and also basing a claim in nuisance. At trial, ${ }^{36}$ the negligence claim was dismissed. The action was allowed, however, on the basis of both nuisance and Rylands v. Fletcher. On appeal,,$^{37}$ the Court held that the rule in Rylands v. Fletcher did not apply. With regard to the nuisance claim, the court held that the defence of statutory authority applied, and that the onus of proving that the occurrence was inevitable had been successfully discharged by the defendant. The case was appealed to the Supreme Court.

The Supreme Court of Canada's judgment involved three separate sets of reasons, which all agreed that the trial judgment should be restored. The Justices were also in agreement that the rule in Rylands $\mathrm{v}$. Fletcher did not apply to the facts of this case. La Forest J., giving reasons on this aspect of the case, held that the rule could not apply to activities which were statutorily authorized, and which were ordinary and proper uses undertaken for the general benefit of the community. This is where the agreement ended, however. On the matter of the claim for nuisance, and the defence of statutory authority, the reasoning was quite different.

Wilson J. wrote the reasons for herself, Lamer and L'Heureux-Dubé JJ. According to Wilson J. the defendant's activity having caused substantial damage to the plaintiffs' home was clearly an actionable nuisance. The liability of the defendant fell to be resolved by applying the defence of statutory authority.

Basing her decision upon the earlier English cases, ${ }^{38}$ Wilson $\mathrm{J}$. held that the applicability of the defence of statutory authority was dependent upon the specific statutory provisions which authorized the nuisance-creating activity

35. (1868), L.R. 3 H.L. 330; 37 L.J.Ex. 161; aff g. L.R. I Ex. 265.

36. (1983), 45 Nfld. \& P.E.I.R. 197, 132 A.P.R. 197.

37. (1986), 62 Nfld. \& P.E.I.R. 133, 190 A.P.R. 133.

38. Especially Metropolitan Asylum District v. Hill (1881), 6 App. Cas. 193, and City of Manchester v. Farnworth, [1930] A.C. 171. 
authorized activities, notwithstanding the "mandatory" or "permissive" nature of the statutory provisions. Having said this, however, Sopinka J.'s approach to the "inevitable consequences" doctrine was very restrictive. The burden of proving inevitable consequences, which falls upon the defendant authority, is a heavy one to discharge. It must be shown that no alternative methods were available for conducting the activity, and in this regard, considerations of expense will not be considered. Merely negating negligence will not suffice; the practical impossibility of avoiding the damage must be shown. Based on this onerous standard, it is not surprising that Sopinka J. found that the defence had not been made out, and that the municipality should be held liable.

Mr. Justice La Forest ${ }^{43}$ reformulated the defence of statutory authority entirely. Referring to an article by then Professor Linden, ${ }^{44}$ La Forest J. noted that the defence was originally developed in order to protect important public and semi-public activities, such as railways, road works, canal works, and hospitals, from legal responsibility for non-negligent conduct. Contemporary concerns, however, dictate not the protection of public authorities at the expense of the individual, but the reverse. The individual should be compensated for the damages caused by public works, the costs of this damage being distributed to the entire public body which benefits from the service.

La Forest J.'s new approach to the defence of statutory authority may be summarized as follows. The defense per se ought to be reserved for only those cases where the legislature has authorized the construction of a work at a particular place. In all other cases, the courts ought to approach the question of the liability of public bodies for nuisance on the same basis as it approaches all nuisance actions, and ask the following question: Given all the circumstances, is it reasonable to refuse to compensate the aggrieved party for the damage which he has suffered as the result of an activity carried out by the public body? The factors which the courts ought to consider in balancing the plaintiff's right to compensation against the defendant's freedom to carry out its activity without this added cost include such things as the nature of the defendant's conduct, the alternatives available to it, the costs of avoiding the damage, the nature of the plaintiff's damage in terms of its severity and frequency, and the utility of the activity. Thus where, as in this case, the plaintiff suffered heavy material damage from a single calamitous event, related to an activity which was of benefit to the public at large, it was, according to La Forest J., reasonable to shift the loss from the plaintiff to the public body. Where, on the other hand, an activity results only in an ordinary disturbance or loss of amenity, which was necessarily incidental to the activity, there being no negligence on the public authority's part, it would be reasonable to require the private individual to bear this inconvenience.

\section{COMMENT}

The judgment in the Tock clearly demonstrates how the principles of nuisance law have been used in order to shift the accident costs of socially beneficial

43. Concurred in by Dickson C.J.

44. Linden, "Strict Liability, Nuisance and Legislative Authorization" (1966) 4 O.H.L.J. 196. 
common law with a principle of strict liability to accommodate the goal of cost distribution, the narrow interpretation given to it, by Tock, and other cases, has frustrated this development.

The source of the difficulty has been the "non-natural use" requirement of the rule. The "non-natural use" requirement of the rule in Rylands v. Fletcher has been the most controversial and uncertain aspect of Lord Cairns' reformulation of the principle of strict liability originally introduced by Blackburn J. Throughout the years, the courts have interpreted this requirement in one of two ways, which choice has dictated whether the strict liability rule in Rylands v. Fletcher would have a limited or broad impact on tort law. The narrow meaning of the phrase has confined the non-natural use requirement to activities which are not only hazardous in nature, but as well unusual, in the sense of out of the ordinary. Stemming from the case of Rickards v. Lothian ${ }^{48}$ this interpretation has eliminated from the scope of strict liability all activities, which although dangerous in their nature, are ordinary and common activities, usually of high utility. Thus, even dangerous activities, such as operating a land fill site which produced explosive gases, ${ }^{49}$ the setting of fires, ${ }^{30}$ and even the use of explosives, ${ }^{51}$ have been excluded from the principle's application on this basis. A broader view of the non-natural use requirement ignores the common or ordinary nature of the activity, and focusses instead on its inherently dangerous nature, and the goal of cost distribution, as being the basis of the rule's application. In this way, the principle is better able to become a vehicle for the distribution of losses arising from necessary, but inherently dangerous activities. ${ }^{52}$

In the Tock case, the Supreme Court has given its support to the more narrow interpretation of the rule. The Supreme Court refused to apply the rule to cases of statutorily authorized activities, which are "ordinary" and "proper" uses of land undertaken for the community's general benefit. This therefore required the Court to adopt the principles of nuisance law in order to accomplish the goal of cost distribution.

The major issue of the case was the defence of statutory authority and it is here where the judgment will have its greatest impact. Despite the fact that the three judgments in the case took decidedly different approaches to the defence, they each, in their own way, restricted its application, making it very unlikely that the defence will be successful in future cases. The approach taken by the Justices to the defence of statutory authority is consistent with the cost distribution goal which underlies the decision.

Wilson J.'s approach to restrict the defence's application to cases of "mandatory" statutory provisions only will significantly limit its scope. As pointed out by Sopinka J., " "modern legislation authorizing the provision of the type of works which frequently give rise to nuisances is almost invariably permissive".

48. [1913] A.C. 263, 82 L.J.P.C. 42.

49. See Gerisen v. Municipality of Toronto (1974), 2 O.R. (2d) 1.

50. See Smith v. Widdicombe (1987), 39 C.C.L.T. 98, aff'd. [1987] 6 W.W.R. 687 (Man. C.A.).

51. See Peirzak v. Rocheleau, [1928] 1 W.W.R. 428.

52. See for example the gas explosion cases, such as North Western Utilities v. London Guarantee, [1936] A.C. 108, and Fenn v. Corp. of Peterborough (1979), 25 O.R. (2d) 399, 9 C.C.L.T. 1. 